\section{Temperature Effects on the Speed and Completion of Germination of 19 Commercially Available Seeded Bermudagrass Cultivars}

\author{
Michael T. Deaton ${ }^{1}$ and David W. Williams
}

ADDITIONAL INDEX WORDS. seeding date, temperature, transition zone, germination characteristics

Summary. The use of seeded bermudagrasses (Cynodon dactylon) is increasing as athletic field and golf course turf. Anecdotal evidence indicates probable and important differences in germination rates among cultivars when established in late spring or early summer. Germination studies were completed in May 2011 in the Turfgrass Science Laboratory at the University of Kentucky on 19 commercially available seeded bermudagrass cultivars. Evaluations for germination rate and total germination under varying temperature regimes representing 20-year average day/ night temperatures for seeding times from 15 May to $1 \mathrm{Aug}$. were conducted to quantify any differences in germination characteristics among cultivars as affected by temperature. There were highly significant differences $(P<0.0001)$ among cultivars in germination rate and total germination when grown under 20-year average day/night temperatures. The cultivars Casino Royale and Riviera consistently represented the fastest/slowest to germinate and highest/lowest total seeds germinated across all temperature regimes, respectively. Significant differences $(P<0.0001)$ were also observed within cultivars for total germination across the temperature regimes tested. The average temperatures of 15 May and 1 Aug. represented slowest/fastest to germinate and lowest/highest total seeds germinated across all temperature regimes, respectively.

$\mathrm{U}$ ntil breeding improvements were made in the "common" type bermudagrasses in the 1980 s and 1990s, sprigging was the most common means of propagation. Seeded cultivars released in the 1990 s finally achieved equal or superior quality characteristics when compared with the interspecific "hybrid" cultivars that had long been the industry standard in medium- to high-maintenance turf applications (Baltensperger and Klingenberg, 1994).

Seeded cultivars provided a substantially lower cost alternative compared with other means of stand establishment (Patton et al., 2004a, 2004 b). In the early years of the 21 st century, research with new seeded bermudagrass cultivars was limited. As more cultivars were made commercially available, studies were conducted to determine optimal seeding rate, date, and fertility requirements (Karcher et al., 2005; Munshaw et al.,
2001; Patton et al., 2004a, 2004b; Shaver et al., 2006).

Continued breeding efforts have led to greater genetic diversity among the cultivars (Yerramsetty et al., 2005). Patton et al. (2008) reported on the establishment vigor of 28 bermudagrass cultivars in the $\mathrm{Na}$ tional Turfgrass Evaluation Program (NTEP) bermudagrass trial that indicated significant differences among cultivars. Establishment vigor was described as a combination of the rates of germination and postgermination seedling growth. However, several of the 28 cultivars in that work were sprigged, and several of the seeded entries were experimental lines and not commercially available.

Previous research on optimal seeding dates has been based on the establishment characteristics of a few to several seeded cultivars. However, with the availability of many newly released cultivars, recommendations for successful establishment protocols arising from previous work may or may not be valid for all cultivars (Patton et al., 2004a).

To that end, it would be useful to investigate what has become apparent anecdotally; i.e., some seeded cultivars tend to be very slow to germinate and difficult to establish, especially relative to other cultivars. The objectives of this study were to quantify the differences among commercially available seeded bermudagrass cultivars in germination rate and total germination, grown under 20-year average temperature regimes representing potential seeding dates in Lexington, $\mathrm{KY}$.

\section{Materials and methods}

Germination studies were conducted in the Turfgrass Science Laboratory on the University of Kentucky campus in 2011. Nineteen commercially available cultivars were evaluated: Arizona "Common" hulled, Arizona "Common" unhulled, Casino Royale, LaPaloma, Mirage II, Mohawk, NuMex Sahara, Princess 77, Riviera, Savannah, Southern Star, Sovereign, SR 9554, Sunbird, Sundevil II, Sunsport, Sunstar, Transcontinental, and Yukon. These cultivars were chosen from a list of commercially available cultivars provided on the NTEP website (Morris, 2010). From a list of more than 20 commercially available cultivars on the NTEP site, only 19 were available through retail distributors. All of the cultivars represented were obtained for field studies in May 2010 and were of the same harvest time and age. The seeds were stored in a $10{ }^{\circ} \mathrm{C}$ walk-in cooler between studies to ensure environmental consistency during storage.

The study design was a completely randomized design with four replications. The experimental unit was a single $100 \times 15-\mathrm{mm}$ petri dish (Fisher Scientific, Pittsburgh, PA) containing $\approx 50$ seeds representing a single cultivar on a double layer of blue blotter paper (CDB 3.25; Anchor Paper Co.,

\footnotetext{
Department of Plant and Soil Sciences, University of Kentucky, Room 310, Plant and Soil Science Building, Lexington, KY 40546-0312

This article was submitted as manuscript 12-06-085 from the University of Kentucky Agricultural Experiment Station.

${ }^{1}$ Corresponding author. E-mail: mike.deaton@uky.edu.
}

\begin{tabular}{llll}
\hline $\begin{array}{l}\text { Units } \\
\begin{array}{l}\text { To convert U.S. to SI, } \\
\text { multiply by }\end{array}\end{array}$ & U.S. unit & SI unit & $\begin{array}{l}\text { To convert SI to U.S., } \\
\text { multiply by }\end{array}$ \\
\hline 29.5735 & fl oz & $\mathrm{mL}$ & 0.0338 \\
25.4 & inch $(\mathrm{es})$ & $\mathrm{mm}$ & 0.0394 \\
$\left({ }^{\circ} \mathrm{F}-32\right) \div 1.8$ & ${ }^{\circ} \mathrm{F}$ & ${ }^{\circ} \mathrm{C}$ & $\left({ }^{\circ} \mathrm{C} \times 1.8\right)+32$
\end{tabular}

Hortlechnology · February $201323(1)$ 
Saint Paul, MN). Each petri dish received $13 \mathrm{~mL}$ water, which allowed for free water in the dish without floating the seeds. Replications were randomly placed in germination chambersmodel SG8F, model SG2-22 (Hoffman Manufacturing, Albany, OR), model I-66LLVL (Percival, Boone, IA), model CMP 3244 (Conviron, Winnepeg, MB, Canada), and model 805 (Precision Scientific, Chennai, India)that were set to individual 20-year calculated averages (data for Lexington, KY) for day and night temperatures, which were $21.5 / 16.3{ }^{\circ} \mathrm{C}$ (15 May), $24.3 / 18.9{ }^{\circ} \mathrm{C}$ (1 June), $27.1 / 21.6^{\circ} \mathrm{C}$ (15 June), $28.3 / 22.8^{\circ} \mathrm{C}$ ( 1 and 15 July), and $29.7 / 23.1{ }^{\circ} \mathrm{C}$ (1 Aug.) with $8 / 16 \mathrm{~h}$ day/night light. Only five temperature settings were used because of the 1 and 15 July temperature averages differing by less than $0.1{ }^{\circ} \mathrm{C}$ for the night temperature with no difference in the day temperature. White fluorescent lamps provided light with a photosynthetic photon flux ranging from 7 to $19 \mu \mathrm{mol} \cdot \mathrm{s}^{-1} \cdot \mathrm{m}^{-2}$. Standard Association of Official Seed Analysts (AOSA) protocol for bermudagrass was followed with regards to light (AOSA, 1998).

Germination counts were made daily for $21 \mathrm{~d}$ postimbibition. Seeds were counted as germinated and removed when the radicle was visible under a $\times 1.75$ magnifying lens. Germination rate [represented by the time to $50 \%$ germination $\left(T_{50}\right)$ ] and percent total germination were calculated. The $T_{50}$ was calculated using a five-parameter Sigmoid regression equation in SigmaPlot 10 (Systat Software, San Jose, CA). Statistical analysis was performed by PROC GLM of SAS (version 9.2; SAS Institute, Cary, NC) at a 0.05 significance level. Means were separated by F-protected Fisher's least significant difference values.

\section{Results}

Highly significant $(P<0.0001)$ differences were observed among cultivars and among temperature regimes for $T_{50}$ for each of the five average temperature dates (Tables 1 and 2). Table 1 also indicates a strong interaction $(P=0.0004)$ between cultivar and temperature regime. 'Riviera' consistently exhibited the slowest $T_{50}$ with respect to cultivar and temperature regime ranging from $13.5 \mathrm{~d}$ (15 May) to $6.3 \mathrm{~d}$ (1 Aug.). 'Transcontinental', 'Casino Royale', and
'Southern Star' exhibited the fastest $T_{50}$ ranging from $4.8 \mathrm{~d}$ (15 May) to $2.5 \mathrm{~d}$ (1 Aug.) with respect to cultivar and temperature regime and were not significantly different. The remaining 15 cultivars tested exhibited what would be considered average $T_{50}$ s based on a normal distribution. As indicated by the significant interaction, $T_{50} \mathrm{~s}$ for all cultivars were lowered as temperature increased because of later simulated seeding dates.

Highly significant differences $(P<0.0001)$ were also observed for the main effect of cultivar, temperature regime, and cultivar $\times$ temperature regime interaction on total percent germination (Tables 3 and 4). 'Riviera' achieved the lowest percent germination across all cultivars and temperature regimes tested ranging from $5.3 \%$ (15 May) to $52.1 \%$ (1 Aug.). 'Casino Royale' achieved the greatest percent germination across all cultivars and temperature regimes ranging from $93.2 \%$ (15 May) to $100 \%$ (1 Aug.). However, 'Casino Royale' was not statistically different from a number of the other cultivars tested for percent germination for four out of five temperature regimes. As with the $T_{50}$ observations, percent germination

Table 1. Analysis of variance for the main effect of bermudagrass cultivar and temperature regime and the cultivar $\times$ temperature regime interaction on germination rate of seed grown under 20-year average day/night temperatures for Lexington, KY.

\begin{tabular}{lrc}
\hline Source of variation & \multicolumn{1}{c}{$\boldsymbol{F}$} & $\boldsymbol{P}>\boldsymbol{F}$ \\
\hline Bermudagrass & 79.51 & $<0.0001$ \\
$\quad$ cultivar $(\mathrm{C})^{\mathrm{z}}$ & & \\
Temperature & 205.52 & $<0.0001$ \\
$\quad$ regime $(\mathrm{T})^{\mathrm{y}}$ & & \\
$\mathrm{C} \times \mathrm{T}$ & 1.81 & 0.0004 \\
$\mathrm{CV}(\%)^{\mathrm{x}}$ & 18.59 & \\
\hline
\end{tabular}

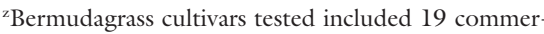
cially available cultivars: Arizona "Common" hulled, Arizona "Common" unhulled, Casino Royale, LaPaloma, Mirage II, Mohawk, NuMex Sahara, Princess 77, Riviera, Savannah, Southern Star, Sovereign, SR 9554, Sunbird, Sundevil II, Sunsport, Sunstar, Transcontinental, and Yukon.

y20-year average temperature regimes: 15 May (21.5/ $\left.16.3^{\circ} \mathrm{C}\right)$, 1 June $\left(24.3 / 18.9^{\circ} \mathrm{C}\right), 15$ June $(27.1 / 21.6$ $\left.{ }^{\circ} \mathrm{C}\right), 1$ and 15 July $\left(28.3 / 22.8^{\circ} \mathrm{C}\right)$, and 1 Aug. (29.7/ $\left.23.1{ }^{\circ} \mathrm{C}\right) ;\left(1.8 \times{ }^{\circ} \mathrm{C}\right)+32={ }^{\circ} \mathrm{F}$.

${ }^{\mathrm{x}}$ Coefficient of variation.

Table 2. Germination rate expressed as time to $50 \%$ germination $\left(T_{50}\right)$ for 19 commercially available cultivars of seeded bermudagrass grown under 20-year average day/night temperatures for Lexington, KY. ${ }^{\mathrm{z}}$

\begin{tabular}{|c|c|c|c|c|c|c|}
\hline \multirow[b]{2}{*}{ Cultivar } & \multicolumn{6}{|c|}{$T_{50}(\mathrm{~d})$} \\
\hline & (15 May) & (1 June) & (15 June) & (1, 15 July) & (1 Aug.) & $\begin{array}{c}\text { Cultivar } \\
\text { LSD }^{\mathrm{y}} \\
\end{array}$ \\
\hline $\begin{array}{l}\text { Arizona "Common" } \\
\text { hulled }\end{array}$ & 6.8 & 3.9 & 3.3 & 3.0 & 2.7 & 0.65 \\
\hline $\begin{array}{l}\text { Arizona "Common" } \\
\text { unhulled }\end{array}$ & 11.5 & 9.1 & 8.1 & 7.6 & 6.1 & 2.78 \\
\hline Casino Royale & 4.9 & 2.9 & 2.8 & 2.8 & 2.5 & 0.36 \\
\hline LaPaloma & 9.3 & 6.2 & 5.3 & 4.9 & 4.1 & 1.62 \\
\hline Mirage II & 7.7 & 5.4 & 4.3 & 3.9 & 4.4 & 0.83 \\
\hline Mohawk & 6.1 & 4.0 & 3.5 & 3.3 & 3.1 & 0.48 \\
\hline NuMex Sahara & 6.6 & 3.3 & 3.3 & 3.2 & 2.8 & 0.29 \\
\hline Princess 77 & 10.8 & 6.2 & 5.2 & 5.3 & 4.9 & 1.83 \\
\hline Riviera & 13.5 & 10.7 & 9.6 & 7.7 & 6.3 & 3.75 \\
\hline Savannah & 6.8 & 4.4 & 4.1 & 3.6 & 3.2 & 0.84 \\
\hline Southern Star & 5.3 & 4.4 & 2.9 & 2.7 & 2.6 & 0.51 \\
\hline Sovereign & 9.7 & 6.4 & 6.3 & 4.6 & 5.0 & 1.26 \\
\hline SR 9554 & 7.3 & 5.7 & 4.8 & 4.2 & 4.1 & 0.89 \\
\hline Sunbird & 6.7 & 4.1 & 3.7 & 3.9 & 3.3 & 0.87 \\
\hline Sundevil II & 6.4 & 3.4 & 3.2 & 3.1 & 2.9 & 0.39 \\
\hline Sunsport & 6.4 & 4.1 & 3.5 & 3.3 & 3.1 & 0.47 \\
\hline Sunstar & 6.5 & 4.2 & 3.4 & 3.5 & 3.1 & 0.67 \\
\hline Transcontinental & 4.8 & 3.2 & 2.9 & 2.7 & 2.6 & 0.60 \\
\hline Yukon & 12.8 & 9.9 & 8.9 & 7.2 & 5.8 & 2.50 \\
\hline Temperature & 2.16 & 1.58 & 1.66 & 0.86 & 0.48 & \\
\hline
\end{tabular}

z20-year average temperature regimes: $15 \mathrm{May}\left(21.5 / 16.3^{\circ} \mathrm{C}\right), 1$ June $\left(24.3 / 18.9^{\circ} \mathrm{C}\right), 15$ June $\left(27.1 / 21.6^{\circ} \mathrm{C}\right)$, $\mathrm{l}$ and $15 \mathrm{July}\left(28.3 / 22.8^{\circ} \mathrm{C}\right)$, and 1 Aug. $\left(29.7 / 23.1^{\circ} \mathrm{C}\right) ;\left(1.8 \times{ }^{\circ} \mathrm{C}\right)+32={ }^{\circ} \mathrm{F}$.

'Fisher's least significant difference at $P \leq 0.05$. 
for the majority of the remaining cultivars tested were average in percent germination in a normal distribution. With increasing temperature, percent

Table 3. Analysis of variance for the main effect of bermudagrass cultivar and temperature regime and the cultivar $\times$ temperature regime interaction on percent germination of seed grown under 20-year average day/night temperatures for

Lexington, KY.

\begin{tabular}{lrc}
\hline Source of variation & \multicolumn{1}{c}{$\boldsymbol{F}$} & $\boldsymbol{P}>\boldsymbol{F}$ \\
\hline $\begin{array}{l}\text { Bermudagrass } \\
\quad \text { cultivar }(\mathrm{C})^{\mathrm{z}}\end{array}$ & 77.82 & $<0.0001$ \\
Temperature & 150.57 & $<0.0001$ \\
$\quad$ regime $(\mathrm{T})^{\mathrm{y}}$ & & \\
$\mathrm{C} \times \mathrm{T}$ & 4.01 & $<0.0001$ \\
$\mathrm{CV}(\%)^{\mathrm{x}}$ & 12.95 & \\
\hline
\end{tabular}

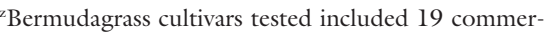
cially available cultivars: Arizona "Common" hulled, Arizona "Common" unhulled, Casino Rovale, LaPaloma, Mirage II, Mohawk, NuMex Sahara, Princess 77, Riviera, Savannah, Southern Star, Sovereign, SR 9554, Sunbird, Sundevil II, Sunsport, Sunstar, Transcontinental, and Yukon.

y20-year average temperature regimes: 15 May (21.5/ $\left.16.3^{\circ} \mathrm{C}\right)$, 1 June $\left(24.3 / 18.9^{\circ} \mathrm{C}\right), 15$ June $(27.1 / 21.6$ $\left.{ }^{\circ} \mathrm{C}\right), 1$ and 15 July $\left(28.3 / 22.8^{\circ} \mathrm{C}\right)$, and 1 Aug. (29.7/

$\left.23.1{ }^{\circ} \mathrm{C}\right) ;\left(1.8 \times{ }^{\circ} \mathrm{C}\right)+32={ }^{\circ} \mathrm{F}$

${ }^{\mathrm{x}}$ Coefficient of variation.

Table 4. Percent germination for 19 commercially available cultivars of seeded bermudagrass grown under 20-year average day/night temperatures for Lexington, KY. ${ }^{\mathrm{z}}$

\begin{tabular}{|c|c|c|c|c|c|c|}
\hline \multirow[b]{2}{*}{ Cultivar } & \multicolumn{6}{|c|}{ Germination (\%) } \\
\hline & (15 May) & (1 June) & (15 June) & (1, 15 July) & (1 Aug.) & $\begin{array}{c}\text { Cultivar } \\
\text { LSD }^{\mathrm{y}} \\
\end{array}$ \\
\hline $\begin{array}{l}\text { Arizona "Common" } \\
\text { hulled }\end{array}$ & 68.2 & 86.2 & 83.1 & 89.0 & 98.3 & 15.03 \\
\hline $\begin{array}{l}\text { Arizona "Common" } \\
\text { unhulled }\end{array}$ & 21.8 & 88.4 & 59.7 & 76.7 & 95.0 & 12.58 \\
\hline Casino Royale & 93.2 & 93.6 & 96.1 & 98.9 & 100.0 & 5.23 \\
\hline LaPaloma & 37.6 & 62.2 & 54.7 & 84.3 & 95.3 & 18.47 \\
\hline Mirage II & 60.8 & 66.9 & 77.3 & 85.3 & 93.8 & 14.46 \\
\hline Mohawk & 73.5 & 88.8 & 87.5 & 95.9 & 74.3 & 30.93 \\
\hline NuMex Sahara & 66.1 & 82.2 & 84.3 & 91.1 & 95.4 & 8.46 \\
\hline Princess 77 & 25.4 & 37.3 & 42.5 & 47.1 & 64.5 & 12.28 \\
\hline Riviera & 5.3 & 5.5 & 17.3 & 23.9 & 52.1 & 16.51 \\
\hline Savannah & 64.1 & 76.4 & 80.9 & 83.5 & 97.1 & 10.96 \\
\hline Southern Star & 75.4 & 81.2 & 86.9 & 92.8 & 96.6 & 8.73 \\
\hline Sovereign & 20.4 & 35.2 & 45.1 & 61.6 & 78.7 & 15.92 \\
\hline SR 9554 & 40.1 & 63.9 & 74.7 & 81.1 & 93.4 & 9.26 \\
\hline Sunbird & 57.4 & 65.4 & 65.1 & 73.8 & 92.2 & 14.85 \\
\hline Sundevil II & 73.0 & 80.7 & 78.0 & 84.2 & 95.9 & 12.49 \\
\hline Sunsport & 76.4 & 77.2 & 88.3 & 92.4 & 96.0 & 13.56 \\
\hline Sunstar & 68.4 & 80.8 & 85.1 & 82.5 & 85.0 & 9.55 \\
\hline Transcontinental & 73.6 & 85.1 & 87.3 & 97.3 & 99.5 & 10.71 \\
\hline Yukon & 15.3 & 47.7 & 72.7 & 77.9 & 85.0 & 10.04 \\
\hline $\begin{array}{l}\text { Temperature } \\
\text { treatment } \mathrm{LSD}^{\mathrm{y}}\end{array}$ & 13.66 & 11.02 & 13.31 & 9.90 & 17.41 & \\
\hline
\end{tabular}

20-year average temperature regimes: $15 \mathrm{May}\left(21.5 / 16.3^{\circ} \mathrm{C}\right), 1$ June $\left(24.3 / 18.9^{\circ} \mathrm{C}\right), 15$ June $\left(27.1 / 21.6^{\circ} \mathrm{C}\right)$, $\mathrm{l}$ and 15 July $\left(28.3 / 22.8^{\circ} \mathrm{C}\right)$, and 1 Aug. $\left(29.7 / 23.1^{\circ} \mathrm{C}\right) ;\left(1.8 \times{ }^{\circ} \mathrm{C}\right)+32={ }^{\circ} \mathrm{F}$

'Fisher's least significant difference at $P \leq 0.05$.

germination increased and the differences among cultivars reduced resulting in much fewer differences among cultivars.

\section{Discussion}

As previously referenced, most of the recent studies evaluating cultivar germination rate or speed and time to cover included only a few of the most popular bermudagrass cultivars. With many new cultivars commercially available and their use increasing in the transitional climatic zone, it was important to complete a study to quantify differences in these parameters. As evidenced by this study, there are significant differences among many of the cultivars with respect to speed and total germination as affected by temperature.

With the recent release of many new cultivars, information concerning establishment and performance has lagged behind; i.e., not all commercially available cultivars have been evaluated. Turfgrass managers in the transitional climatic zone are major consumers of seeded bermudagrasses.
This study shows that in the upper transitional climatic zone, conventional recommended seeding dates are not necessarily applicable to all of the commercially available cultivars of bermudagrass. Although most of the cultivars obtain greater than $80 \%$ germination, this may not occur until the warmer temperatures of August. Seeding bermudagrass in August in the transition zone could put the manager at a much greater risk for stand failure that would not be realized until the following spring. With a much shorter time to establish proper food reserves, the chances of stand failure due to winterkill would increase significantly for most areas in the transitional climatic zone. Some of the cultivars evaluated, such as Riviera, Princess 77, and Sovereign, struggled to obtain $80 \%$ germination at the temperatures that would normally be expected during the recommended seeding dates of mid-May to mid-June.

We conclude that there are vast differences in germination characteristics among the cultivars tested. Methods that have been accepted as standard (e.g., early June seeding date defined as optimal) may now be called into question for some cultivars seeded in the upper transition zone. Considering the many cultivars available today, genetic diversity likely contributes to the differences in performance characteristics. Temperature plays a definite and determining role in the ability of seeded bermudagrass cultivars to complete the germination process. In the upper transitional climatic zone, temperatures do not reach optimal levels for the germination of several cultivars until July. 'Riviera' and 'Princess 77', which are two of the highest quality cultivars, have enormous difficulty completing germination in an upper transitional climatic zone environment at the normal recommended seeding date of 1 June. Future research should investigate the physiological mechanisms linked to temperature that may be impeding the completion of the germination process. In addition, and perhaps more importantly, turfgrass managers should determine if the establishment time required for a specific intended use will coincide with the expected environmental conditions before choosing a cultivar. 


\section{Literature cited}

Association of Official Seed Analysts. 1998. Methods of testing for laboratory germination, p. 68. In: AOSA rules for testing seeds. Association of Official Seed Analysts, Ithaca, NY.

Baltensperger, A.A. and J.P. Klingenberg. 1994. Introducing new seed-propagated $\mathrm{F}_{1}$ hybrid (2-clone synthetic) bermudagrass. U.S. Golf Assn. Green Section Record 32:14-19.

Karcher, D.E., M.D. Richardson, J.W. Landreth, and J.H. McCalla. 2005. Recovery of bermudagrass varieties from divot injury. Appl. Turfgrass Sci. 15 Oct. 2012. $<$ http://www.plantmanagementnetwork. org/pub/ats/research/2005/divot/>.
Morris, K.N. 2010. Data progress report. 2007 National Bermudagrass Test. NTEP No. 11-4. 26 Nov. 2012. <http://www. ntep.org/reports/bg07/bg07_11-4/ bg07_11-4.htm>.

Munshaw, G.C., D.W. Williams, and P.J. Cornelius. 2001. Management strategies during establishment year enhance production and fitness of seeded bermudagrass stolons. Crop Sci. 41:1558-1564.

Patton, A.J., G.A. Hardebeck, D.W. Williams, and Z.J. Reicher. 2004a. Establishment of bermudagrass and zoysiagrass by seed. Crop Sci. 44:2160-2167.

Patton, A.J., M.D. Richardson, D.E. Karcher, J.W. Boyd, Z.J. Reicher, J.D. Fry, J.S. McElroy, and G.C. Munshaw. 2008. A guide to establishing seeded bermudagrass in the transition zone. Appl.
Turfgrass Sci. 15 Oct. 2012. <http:// www.plantmanagementnetwork.org/ pub/ats/guide/2008/bermudagrass/>.

Patton, A.J., D.W. Williams, and Z.J. Reicher. 2004b. Establishing seeded bermudagrass. Golf Course Mgt. 26 Nov. 2012. <http://www2.gcsaa.org/GCM/ 2004/dec04/pdf/Estseedbermuda7377.pdf>.

Shaver, B.R., M.D. Richardson, J.H. McCalla, D.E. Karcher, and P.J. Berger. 2006. Dormant seeding of bermudagrass cultivars in a transition-zone environment. Crop Sci. 46:1787-1792.

Yerramsetty, P.N., M.P. Anderson, and C.M. Taliaferro. 2005. DNA fingerprinting of seeded bermudagrass cultivars. Crop Sci. 45:772-777. 